Arab Univ. J. Agric. Sci., Ain Shams Univ., Cairo, 14(2), 697-710, 2006

\title{
PRODUCTION OF PROBIOTIC LOW-CALORIE SOUR CREAM
}

[44]

\author{
Fayed $^{1}$, A.E.; Gehan A.M. Hussein ${ }^{1}$ and Azza M. Farahat ${ }^{1}$
}

\begin{abstract}
The production of probiotic low calorie sour cream was aimed to experiment in relation to its compositional, bacteriological, biochemical, rheological and organoleptic properties along the cold storage period of the product. Cream based on $36 \%$ total solids (TS) and $30 \%$ fat was made using the obtained fresh cream (54\% TS and $50 \%$ fat) and liquid skimmed milk (9\% TS).To produce low-calorie sour cream, fat content was lowered to 20 and $10 \%$ depending on the addition of Simplesse $100^{\circledR}$ to mimic milk fat on the basic of $0.1 \%$ fat mimetic is instead of $1.0 \%$ fat. Dried whey protein concentrate (DWPC, $95 \% \mathrm{TS}$ ) was used as bulking agent to overcome the loss occurred in the TS content due to the reduction in the fat content. Thereafter, all creams were homogenized at $55-60^{\circ} \mathrm{C}$ and further heat treated to $74^{\circ} \mathrm{C}$ for $30 \mathrm{sec}$. followed by rapidly cooling to the appropriate temperatures. Then creams were inoculated with $2 \%$ freshly prepared bacterial starter culture and incubated at 30 or $37{ }^{\circ} \mathrm{C}$, to reach $\mathrm{pH}$ value about 4.6 , for cream cultured with R-704 or ABT-2 type starter culture, respectively. The results indicated that, the proportional fat replacement of cream led to gradual increase in the protein, carbohydrate and ash contents, and decreased the caloric value. There are a backward relationship between the bacterial population and the fat content of the sour cream. Where, in the product cultured with ABT-2 type, Lactobacillus acidophilus grew and predominated in all other accompanying strains overlooking either the fat content or the cold storage period (CSP). Streptococcus thermophilus populated the $2^{\text {nd }}$ predominance order followed by Bifidobacterium sp., which tended to proximate and preceded, actually, Str. thermophilus by prolonging the CSP of the lowest fat-content cream (10\%). The increase rate of the bacterial count continued until $3^{\text {rd }}$ weak for Lb. acidophilus and to $1^{\text {st }}$ weak for Bifidobacterium sp.. Thereafter, gradual decreases were occurred. However, Str. thermophilus began to decrease from the $1^{\text {st }}$ day of CSP. Although the count of bacterial type R-704 was always higher, it behaved a trend similar to that of Bifidobacterium sp. toward the CSP. Sour cream of ABT-2 type contained higher titratable acidity (TA) \% as well as lower $\mathrm{pH}$, acetaldehyde (AC) and diacetyl (DA) values than that cultured with R-704 type. Along CSP of sour cream the increment in AC, DA and TA contents continued, in order, until the $7^{\text {th }}, 14^{\text {th }}$ and the end of the
\end{abstract}

1- Food Science Dept., Fac. Agric., Ain Shams Univ., Shoubra El-Khaima, Cairo, Egypt

(Received May 7, 2006)

(Accepted May 22, 2006) 
experimental period. As the protein content raised at the expanse of the fat content via adding DWPC, which was in the denatured form, the firmness, consistency coefficient, and yield stress of sour cream increased, especially when ABT-2 type was used and the CSP progressed. Furthermore, ABT-2 sour cream was sensory distinguished with, nearly, similar appearance as will as better flavour and consistency rather than that of R-704. The fat reduction to $20 \%$ did not influence the overall sensory quality, while that of $10 \%$ fat attained panel score averaged $93.5 \%$ of the control when ABT-2 type was used. As a conclusion, it is successfully possible to produce probiotic low calorie sour cream with excellent sensory attributes using Simplesse $100^{\circledR}$ as fat mimetic and bacterial type ABT-2 as starter culture.

Keywords: Sour cream, Rheological profile, Lactobacillus acidophilus, Streptococcus thermophilus, Bifidobacterium sp., Simplesse ${ }^{\circledR}$

\section{INTRODUCTION}

The human gastrointestinal tract is a diverse and complex ecosystem harboring more than 400 species of bacteria. Their importance is demonstrated by their impressive presence. The large intestine alone contains about $1.5 \mathrm{Kg}$ of bacteria. This quantity of bacteria is not surprising given the tremendous effect of bacterial growth and metabolism on human health. Not all bacteria are created or act equally, however, some benefit the body and are required for optimal health, whereas others harm the body by producing toxins and even carcinogens. An optimal balance of microbial organisms in the intestine is an important aspect of maintaining good health (Hekmat \& McMahon, 1992). When lactic acid-producing bacteria are in short supply, undesirable bacteria can increase in number. The results can range from simple digestive discomfort to more serious gastrointestinal disease. Imbalance - a scarcity of "good" bacteria or a surplus of "bad" bacteria can set the stage for a cascade of events that may ultimately trigger disease. Certain bacteria, such as Bifidobacterium sp.,
Lactobacillus acidophilus, Lb. casei, Lb. returei, Lb. delbrueckii ssp. bulgaricus and Streptococcus thermophilus help maintain such a favorable balance (Hansen, 1985). Bifidobacteria are the predominant gut flora in breastfed infants, where they prefer to reside in the large intestine. While, Lb. acidophilus can survive in abundance in the small intestine. As person ages, the number of intestinal bifidobacteria decrease and the numbers of clostridia, streptococci and coliforms increase (Start \& Lee, 1982; Rasic \& Kurmann, 1983 and Hoover, 1993).

The health, whether the prophylactic or therapeutic, and nutritional benefits ascribed to both Bifidobacterium sp. and $L b$. acidophilus are many and variable, including potential roles in human intestinal tract, anti-carcinogenic effect by suppressing the formation of cancercausing amines and cancer-promoting enzymes in the intestine. Increasing immune-competence and antagonistic effect toward enteropathogenic bacteria by producing antibiotics and organic acids as well as lowering the $\mathrm{pH}$ of the colon. Besides, they act as barriers to prevent pathogenic bacteria from colonizing the 
intestines,aiding absorption of minerals, especially calcium, due to increasing intestinal acidity and improving the lactose digestibility for lactose maldigestors. Moreover, the consumption of such strains interferes with cholesterol absorption from intestine leading to reduce its level in the blood serum. The dietary administration of them in patients with hepatic disease reduces ammonia, free serum phenol and free amino nitrogen in the blood. Furthermore, they are resistant to intestinal bile salts and produce vitamins, especially B-vitamins and vitamin $\mathrm{K}$ (Poupard et al 1973; Harrison \& Peat 1975; Oda et al 1983; Rasic, 1983; Kim \& Gilliland, 1984; Anand et al 1984; Robinson, 1991 and Kebary et al 1998).

In recent years, because of their reported health benefits, the dairy industry has begun incorporating probiotic cultures into many products such as yoghurt and cheese. Besides, some trials have been carried out for the production of probiotic sour cream (El-Kenany, 1996 and Wilson et al 2004). But, it becomes logic to suppose that, it would be more suitable to improve the beneficial purpose of this product when probiotic strains are rather cultured in the low calorie cream preferring rich in protein. Especially, with the current upward trend in nutritional and health awareness, the consumer's demand for reduced or low calorie food has been accelerated (Tharp \& Gottemoller 1990; Coninck 1996 and Fayed et al 2006).

Therefore, the aim of this work was to study the overlapping influences of the partial fat mimetic in addition to the cream culturing with probiotic strains on the varied attributes of the resultant sour cream.

\section{MATERIAL AND METHODS}

\section{Materials}

Fresh buffalo's milk was obtained from the herd of Fac. Agric., Ain Shams Univ., Egypt. Dried whey protein concentrate (consisted of $95 \%$ dry matter, $68 \%$ protein, $14 \%$ lactose, $12 \%$ ash and less than $0.5 \%$ fat) made by SFK DATABIAD, Hvidovre and Viborg, Denmark, was obtained from the local market. Simplesse $100^{\circledR}$ (modified dairy whey concentrate) made by CPKelco, Penrhyn Road, Knowsley Business Park, Denmark, was obtained from the Egyptian Office for Trading and Agencies (eta), Cairo. Tow commercial lyophilized bacterial cultures were obtained from Chr. Hansen Laboratory, Copenhagen, Denmark. The first one was mesophilic homofermentative culture type R-704 DVS and the second was thermophilic culture type ABT-2 DVS containing $L b$. acidophilus, Bifidobacterium sp. and Str. thermophilus.

\section{Experimental procedure}

\section{Cream separation}

Fresh cream (54\% total solids and $50 \%$ fat) was mechanically separated from fresh buffalo's milk.

\section{Preparation of bacterial starter cul- tures}

Lyophilized bacterial cultures were separately inoculated in previously autoclaved $\left(121^{\circ} \mathrm{C} / 15 \mathrm{~min}\right.$.) skimmed milk and incubated at $30^{\circ} \mathrm{C}$ for the type R-704 or at $37^{\circ} \mathrm{C}$ for the ABT-2 type. The complete curdling occurred within $8 \mathrm{~h}$. Starter cultures were freshly used. 


\section{Preparation of sour cream}

Cream based on $36 \%$ total solids (TS) and $30 \%$ fat was made using the obtained fresh cream and liquid skimmed milk (9 \% TS). To produce low-calorie sour cream, fat content was lowered to 20 and $10 \%$ depending on the addition of Simplesse $100^{\circledR}$ to mimic milk fat on the basic of $0.1 \%$ fat mimetic is instead of $1.0 \%$ fat. Dried whey protein concentrate (DWPC) was used as bulking agent to overcome the loss occurred in the TS content due to the reduction in the fat content (Table, 1). The quantities of DWPC and liquid skimmed milk required for low-calorie cream blends were calcu- lated by fitting their compositions to the equations suggested by Fayed $\boldsymbol{e t} \boldsymbol{a l}$ (2006). Thereafter, all creams were homogenized using X520, UAC 30-R, Chicago II G064 (3000 rpm/min.) homogenizer at $55-60^{\circ} \mathrm{C}$ and further heat treated to $74^{\circ} \mathrm{C}$ for $30 \mathrm{sec}$. followed by rapidly cooling to the appropriate temperatures. Then, creams were inoculated with $2 \%$ freshly prepared bacterial starter culture and incubated at 30 or $37^{\circ} \mathrm{C}$, to reach $\mathrm{pH}$ value of about 4.6, for cream cultured with R-704 or ABT-2 type starter culture, respectively. The resultant sour creams were held 21 days at refrigerator temperature $\left(7 \pm 1^{\circ} \mathrm{C}\right)$ for 7 days interval analyses. Three replicates were carried out for every treatment.

Table 1. Low calorie sour cream blends $(\mathrm{kg} / 100 \mathrm{~kg})$

\begin{tabular}{|lccc|}
\hline \multirow{2}{*}{ Ingredient } & \multicolumn{3}{c|}{ Designed fat content } \\
\cline { 2 - 4 } & $30 \%$ & $20 \%$ & $10 \%$ \\
\hline Cream (54 \% TS,50 \% fat) & 60.00 & 40.00 & 20.00 \\
Skim milk (9\% TS) & 40.00 & 47.92 & 58.35 \\
Simplesse 100 & 0.00 & 1.00 & 2.00 \\
DWPC (95\% TS) & 0.00 & 11.08 & 19.65 \\
\hline
\end{tabular}

\section{Analytical methods}

Dry matter, fat, total nitrogen, ash and titratable acidity contents were determined (AOAC, 2000). Acetaldehyde (AC) and diacetyl (DA) contents were determined according to Lees \& Jago (1969) and (1970), respectively. $\mathrm{pH}$ values was measured using $\mathrm{pH}$ meter model Cole-Armer Instrument Co., USA. Rheological parameters were measured using a
Coaxial rotational viscometer (Rheotest II, Medingen, Germany) at $10 \pm 1^{\circ} \mathrm{C}$ at shear rates ranging from 3 to $1312 \mathrm{sec}^{-1}$. Consistency coefficient and yield stress were calculated from the ascending flow curve as described by Toledo (1980) and Bourne (1982), respectively. While, the firmness was measured at $10 \pm 1^{\circ} \mathrm{C}$ using penetrometer model SUR, BERLIN, PNR6 as described by Bourne (1982). The depth (per mm) to which a loaded 
perforated disc (cone weight $41.4570 \mathrm{~g}$, total $49.7820 \mathrm{~g}$ ) penetrates into the set sour cream in given time $(5 \mathrm{sec}$.) is recorded. Caloric value was calorimeterically determined according to the method described by Walstra \& Jenness (1984). While the theoretic caloric value was calculated using figures of Renner \& Renz-Schauen (1986). Samples were prepared for the bacterial analyses as in Marshall (1992). Mesophilic bacteria type R-704 were enumerated, using M17 agar medium, after the incubation at $30^{\circ} \mathrm{C}$ for $48 \mathrm{~h}$. as in Terzaghi \& Sandine (1975). Whilst, Str. thermophilus, Lb. acidophilus and Bifidobacterium sp. were enumerated using ST agar, MRS-sorbitol agar and MRS (Oxoid) agar supplemented with L-cystein and lithium chloride, respectively, after the incubation at $37^{\circ} \mathrm{C}$ for $72 \mathrm{~h}$ as in Dave and Shah (1996). Organoleptic evaluation was carried out according to the scheme of Bodyfelt et al (1988). The obtained data were statistically analyzed according to SPSS (1998).

\section{RESULTS AND DISCUSSION}

\section{Gross composition of sour cream prior culturing}

As present in Table (2), the proportional fat replacement in cream yielded an increase in the protein, carbohydrate and ash contents $(p<0.01)$ since the DWPC (68\% protein, $14 \%$ lactose and $12 \%$ ash) was used as bulking agent to maintain the TS $\%$, of cream at the designed level of $36 \%$. Similar observations were reported by Fayed et al (2006).

\section{Energy load of sour cream}

As shown also in Table (2), the caloric value of sour cream, whether calorimetrically determined or theortically calculated, decreased gradually as the fat was replaced by Simplesse $100^{\circledR}$. Moreover, the figures obtained by the former method were, at any given fat content, about the double of those theoretically expressed. Similar findings were reported by Fayed et al (2006).

Table 2. Gross composition and caloric value of sour cream prior culturing as affected by the fat replacement with Simplesse $100^{\circledR}$

\begin{tabular}{|lccc|}
\hline \multirow{2}{*}{ Property } & \multicolumn{3}{c|}{ Designed fat content } \\
\cline { 2 - 4 } & $30 \%$ & $20 \%$ & $10 \%$ \\
\hline Total solids \% & 36.15 & 36.20 & 36.10 \\
Fat \% & 30.20 & 20.15 & 10.10 \\
Total protein \% (TN x 6.38) & 2.27 & 10.60 & 17.35 \\
Carbohydrate \%* & 3.68 & 5.45 & 8.65 \\
Ash \% & 0.58 & 0.76 & 0.92 \\
Calorimeterical caloric value (K. cal/100g) & 607.9 & 513.9 & 402.8 \\
Theoretical caloric value (K. cal/100g) & 305.3 & 253.2 & 200.5 \\
\hline
\end{tabular}

* Calculated by the difference. 


\section{Bacterial population of sour cream}

Data given in Table (3) reveal that as beginning, there are reverse relationships between the fat content and the bacterial count among all strains experimented in sour cream whether when fresh or along the cold storage period $(p<0.01)$. That would clearly indicate that the fat reduction may improve the bacterial viability in sour cream. Besides, the sour cream solids recovery by adding DWPC could be considered at the same time as growthfactors supplementation for the sour cream medium.

Regarding the bacterial strains contributing the ABT-2 type starter culture, $L b$. acidophilus predominated in all other accompanying strains $(\mathrm{p}<0.01)$ overlooking either the fat content of cream or the cold storage period. Str. thermophilus populated the second predominance order followed by Bifidobacterium sp., which stilled to live and grow until the end of the experimental period (21 days), so that it approximated and preceded Str. thermophilus if the fat content of cream was lowered to $10 \%$ occupying its predominated position, i.e. the second order (Table, 3). As the cold storage period pro longed, the count of Lb. acidophilus continued strongly to increase until the $3^{\text {rd }}$ weak ranging $\log 7.91-8.04$, i.e. $8.1 \times 10^{7}$ $1.1 \times 10^{8} \mathrm{cfu} / \mathrm{g}$ sour cream. The highest count belonged to the lowest fat content and visa versa. Then it began to decrease. Nevertheless, the count of Str. thermophilus started to decline from the first day of cold storage period. However, Bifidobacterium sp. remained increasingly grow until the $1^{\text {st }}$ week log counted $5.73-6.84$, i.e. $5.4 \times 10^{5}-6.9 \times 10^{6} \mathrm{cfu} / \mathrm{g}$ sour cream. The highest count pertained to the lowest fat content and visa versa. Then it fol- lowed by gradual reduction as the cold storage period progressed therefore. But it stilled to possess valuable count $\left(10^{5}\right.$ $10^{6} \mathrm{cfu} / \mathrm{g}$ ) as good as recommended by Schuler-Malyoth et al (1968) and Kurmann \& Rasic (1991). Likewise, the mesophilic bacteria of starter culture type R-704 exhibited a growth behavior like to that of Bifidobacterium sp., where their count increased to $\log 7.94-9.00$, i.e. $8.7 \times 10^{7}-1 \times 10^{9} \mathrm{cfu} / \mathrm{g}$, in inverse order with the fat content, at the end of the $1^{\text {st }}$ week then it trended gradually to decrease as the cold storage period of sour cream prolonged. These results agree with those reported by El-Kenany (1996).

\section{Biochemical properties of sour cream}

As seen in Table (4), the titratable acidity (TA\%), acetaldehyde (AC) and diacetyl (DA) contents of sour cream increased and hence the $\mathrm{pH}$ value decreased as the fat content reduced by replacing it with Simplesse $100^{\circledR}(p<0.01)$ indicating the foregoing finding of such relationship between the fat content and bacterial viability. Moreover, the acidity produced by ABT- 2 type starter culture was significantly $(p<0.01)$ higher than that formed by R-704 type in sour cream, whether when fresh or cold stored, although, both of AC and DA produced by the former starter culture were lower than those produced by the latter.

By duration of the cold storage of sour cream, the TA\% increased gradually as well as the $\mathrm{pH}$ value proportionally decreased providing that the highest TA\% remained always so at a certain any period of the cold storage $(p<0.01)$. 
Table 3. Bacterial log count $\left(\mathrm{cfu}^{1} / \mathrm{g}\right)$ of sour cream during cold storage period as affected by the fat replacement with Simplesse $100^{\circledR}$ as well as the kind of bacterial starter culture.

\begin{tabular}{|c|c|c|c|c|c|c|c|c|c|c|c|c|}
\hline \multirow{4}{*}{$\begin{array}{l}\text { Cold } \\
\text { storage } \\
\text { period } \\
\text { (day) }\end{array}$} & \multicolumn{12}{|c|}{ Designed fat content } \\
\hline & \multicolumn{4}{|c|}{$30 \%$} & \multicolumn{4}{|c|}{$20 \%$} & \multicolumn{4}{|c|}{$10 \%$} \\
\hline & \multirow{2}{*}{ R-704 } & \multicolumn{3}{|c|}{ ABT $-2^{3}$} & \multirow{2}{*}{ R-704 } & \multicolumn{3}{|c|}{ ABT-2 } & \multirow{2}{*}{ R-704 } & \multicolumn{3}{|c|}{ ABT-2 } \\
\hline & & $\mathrm{A}^{4}$ & B & $\mathrm{T}$ & & A & B & $\mathrm{T}$ & & A & $\mathrm{B}$ & $\mathrm{T}$ \\
\hline 0 & 7.30 & 7.46 & 4.00 & 6.34 & 8.26 & 7.69 & 5.36 & 6.51 & 8.88 & 7.89 & 6.89 & 6.71 \\
\hline 7 & 7.94 & 7.83 & 5.73 & 4.48 & 8.70 & 7.93 & 5.54 & 5.61 & 9.00 & 8.00 & 6.84 & 6.67 \\
\hline 14 & 6.96 & 7.91 & 4.40 & 3.90 & 7.63 & 7.98 & 4.85 & 4.69 & 7.91 & 8.04 & 5.60 & 5.60 \\
\hline 21 & 6.58 & 6.83 & 2.34 & 3.30 & 7.18 & 6.90 & 3.04 & 4.23 & 7.34 & 6.93 & 4.43 & 4.32 \\
\hline
\end{tabular}

${ }^{1} \mathrm{cfu} / \mathrm{g}$ : Colony forming unit per gram. $\quad{ }^{2} \mathrm{R}-704$ : mesophilic homofermentative culture.

${ }^{3}$ ABT-2: thermophilic culture. $\quad{ }^{4}$ A: Lb. acidophilus $\quad$ B: Bifidobacterium sp. T: Str. thermophilus

Table 4. Biochemical properties of sour cream during cold storage period as affected by the fat replacement with Simplesse $100^{\circledR}$ as well as the kind of bacterial starter culture.

\begin{tabular}{|c|c|c|c|c|c|c|}
\hline \multirow{3}{*}{$\begin{array}{l}\text { Cold storage period } \\
\text { (day) }\end{array}$} & \multicolumn{6}{|c|}{ Designed fat content } \\
\hline & \multicolumn{2}{|c|}{$30 \%$} & \multicolumn{2}{|c|}{$20 \%$} & \multicolumn{2}{|c|}{$10 \%$} \\
\hline & $\mathrm{R}-704^{*}$ & ABT $-2^{*}$ & $\mathrm{R}-704$ & ABT-2 & R-704 & ABT-2 \\
\hline & \multicolumn{6}{|c|}{ Titratable acidity \% (as lactic acid) } \\
\hline 0 & 0.70 & 0.75 & 0.72 & 0.77 & 0.78 & 0.83 \\
\hline 7 & 0.73 & 0.78 & 0.76 & 0.81 & 0.83 & 0.89 \\
\hline 14 & 0.75 & 0.80 & 0.78 & 0.84 & 0.87 & 0.94 \\
\hline \multirow[t]{2}{*}{21} & 0.76 & 0.81 & 0.79 & 0.85 & 0.89 & 0.97 \\
\hline & \multicolumn{6}{|c|}{$\mathrm{pH}$ value } \\
\hline 0 & 4.65 & 4.62 & 4.63 & 4.60 & 4.60 & 4.55 \\
\hline 7 & 4.60 & 4.58 & 4.58 & 4.57 & 4.56 & 4.54 \\
\hline 14 & 4.57 & 4.55 & 4.55 & 4.54 & 4.53 & 4.52 \\
\hline 21 & 4.55 & 4.53 & 4.53 & 4.52 & 4.51 & 4.50 \\
\hline & \multicolumn{6}{|c|}{ Acetaldehyde $(\mu \mathrm{mol} / \mathrm{ml})$} \\
\hline 0 & 239 & 173 & 265 & 188 & 298 & 195 \\
\hline 7 & 244 & 181 & 297 & 225 & 314 & 220 \\
\hline 14 & 238 & 175 & 251 & 201 & 283 & 185 \\
\hline \multirow[t]{2}{*}{21} & 198 & 124 & 205 & 189 & 248 & 135 \\
\hline & \multicolumn{6}{|c|}{ Diacetyl $(\mu \mathrm{mol} / \mathrm{ml})$} \\
\hline 0 & 55 & 3 & 95 & 7 & 118 & 8 \\
\hline 7 & 84 & 11 & 118 & 13 & 135 & 17 \\
\hline 14 & 103 & 19 & 138 & 27 & 158 & 25 \\
\hline 21 & 90 & 11 & 126 & 17 & 140 & 18 \\
\hline
\end{tabular}

"See Table: 3 . 
The increment rate in the $\mathrm{AC}$ content continued until the $2^{\text {nd }}$ week, while that of DA content continued up to $3^{\text {rd }}$ week, then reductions were took place in both components by prolonging the period of cold storage $(p<0.01)$. This trend is in coincidence with that found by ElKenany (1996).

\section{Rheological profile of sour cream}

Data displayed in Table (5) appear that, all rheological parameters measured namely the firmness, which reflected from the penetration value, consistency coefficient and yield stress, raised as the fat reduced $(p<0.01)$. These phenomena might be related to the increase in the protein content rather than the reduction in the fat content of sour cream because of its increasingly forward reaction toward the developed acidity during cold storage period, especially the whey proteins of the bulking agent used were in the denatured form, i.e. they would behave completely as casein towards acid. Besides, their attained water holding capacity due to the denaturization. Similar observations were reported by ElKenany (1996) and Fayed et al (2006) toward the duration of cold storage of sour cream and protein enrichment of whipped cream, respectively.

Concerning the kind of starter culture, the sour cream cultured with the type of ABT-2 achieved always the higher figures for the consistency coefficient and yield stress and consequently the lower penetration value vis-à-vis that cultured with the type of R-704 $(\mathrm{p}<0.01)$, that could be explained by the relatively higher acidity attained in the former (Table, 4).

\section{Organoleptic quality of sour cream}

Organoleptically, the appearance of sour cream was not influenced by the partial replacement of fat by Simplesse $100^{\circledR}$ except of some yellowness in colour seemed due to the increasing level of bulking agent (DPWC) that led sour cream to attain also a body firmer than that of the control (Table, 6). Similar observations were reported by Fayed $\boldsymbol{e t}$ al (2006). A slight increment in the consistency score was recorded towards the sour cream cultured by bacterial starter type ABT-2. The effect of variability in the kind of bacterial starter culture became more pronounced with regard to the flavour criterion of the product. Where, the type ABT-2 imparted it palatability better than that gained when the type R704 was used. All samples kept, along the cold storage period, their sensory quality being nearly as good as their fresh ones with slight reduction in the panel score, especially when the culture type R-704 was used.

As a conclusion, it is successfully possible to produce probiotic low calorie sour cream with excellent sensory attributes using Simplesse $100^{\circledR}$ as fat mimetic and bacterial type ABT-2 as starter culture. 
Table 5. Rheological parameters of sour cream during cold storage period as affected by the fat replacement with Simplesse $100^{\circledR}$ as well as the kind of bacterial starter culture.

\begin{tabular}{|c|c|c|c|c|c|c|}
\hline \multirow{3}{*}{$\begin{array}{l}\text { Cold storage period } \\
\text { (day) }\end{array}$} & \multicolumn{6}{|c|}{ Designed fat content } \\
\hline & \multicolumn{2}{|c|}{$30 \%$} & \multicolumn{2}{|c|}{$20 \%$} & \multicolumn{2}{|c|}{$10 \%$} \\
\hline & $\mathrm{R}-704^{*}$ & ABT $-2^{*}$ & $\mathrm{R}-704$ & ABT-2 & $\mathrm{R}-704$ & ABT-2 \\
\hline & \multicolumn{6}{|c|}{ Penetration value (mm) } \\
\hline 0 & 21.5 & 21.8 & 22.2 & 23.0 & 23.5 & 24.1 \\
\hline 7 & 21.9 & 22.2 & 22.6 & 23.3 & 23.9 & 24.5 \\
\hline 14 & 22.4 & 22.8 & 23.2 & 23.7 & 24.2 & 24.9 \\
\hline \multirow[t]{2}{*}{21} & 23.1 & 23.5 & 23.9 & 24.2 & 24.7 & 25.3 \\
\hline & \multicolumn{6}{|c|}{ Consistency coefficient (dyne.sec./cm²) } \\
\hline 0 & 20.74 & 21.49 & 23.57 & 23.79 & 24.37 & 24.55 \\
\hline 7 & 22.03 & 22.81 & 25.62 & 25.88 & 25.10 & 27.14 \\
\hline 14 & 23.23 & 24.00 & 27.10 & 27.53 & 28.32 & 29.08 \\
\hline \multirow[t]{2}{*}{21} & 24.68 & 25.02 & 28.00 & 28.62 & 29.14 & 30.16 \\
\hline & \multicolumn{6}{|c|}{ Yield stress (dyne./$\left./ \mathrm{cm}^{2}\right)$} \\
\hline 0 & 135.05 & 189.13 & 203.53 & 216.40 & 306.79 & 333.01 \\
\hline 7 & 146.41 & 200.30 & 244.62 & 253.14 & 346.43 & 390.31 \\
\hline 14 & 160.12 & 239.14 & 290.31 & 310.81 & 392.15 & 435.00 \\
\hline 21 & 178.36 & 275.50 & 303.45 & 344.52 & 425.50 & 480.66 \\
\hline
\end{tabular}

*See Table: 3 . 
Table 6. Organoleptic scores of sour cream during cold storage period as affected by the fat replacement with Simplesse $100^{\circledR}$ as well as the kind of bacterial starter culture

\begin{tabular}{|c|c|c|c|c|c|c|}
\hline \multirow{3}{*}{$\begin{array}{l}\text { Cold storage period } \\
\text { (day) }\end{array}$} & \multicolumn{6}{|c|}{ Designed fat content } \\
\hline & \multicolumn{2}{|c|}{$30 \%$} & \multicolumn{2}{|c|}{$20 \%$} & \multicolumn{2}{|c|}{$10 \%$} \\
\hline & $\mathrm{R}-704^{*}$ & $\mathrm{ABT}-2^{*}$ & R-704 & ABT-2 & $\mathrm{R}-704$ & ABT-2 \\
\hline & \multicolumn{6}{|c|}{ Appearance (25) } \\
\hline 0 & 25 & 25 & 23 & 23 & 20 & 20 \\
\hline 7 & 25 & 25 & 23 & 23 & 20 & 20 \\
\hline 14 & 24 & 24 & 23 & 23 & 20 & 20 \\
\hline \multirow[t]{2}{*}{21} & 23 & 24 & 21 & 23 & 18 & 19 \\
\hline & \multicolumn{6}{|c|}{ Consistency (25) } \\
\hline 0 & 25 & 25 & 25 & 25 & 24 & 24 \\
\hline 7 & 25 & 25 & 25 & 25 & 23 & 24 \\
\hline 14 & 25 & 24 & 25 & 25 & 22 & 23 \\
\hline \multirow[t]{2}{*}{21} & 24 & 24 & 23 & 24 & 20 & 23 \\
\hline & \multicolumn{6}{|c|}{ Flavour (50) } \\
\hline 0 & 50 & 50 & 50 & 50 & 45 & 48 \\
\hline 7 & 48 & 50 & 46 & 50 & 43 & 48 \\
\hline 14 & 46 & 48 & 43 & 49 & 40 & 46 \\
\hline \multirow[t]{2}{*}{21} & 45 & 47 & 41 & 49 & 38 & 45 \\
\hline & \multicolumn{6}{|c|}{ Total score (100) } \\
\hline 0 & 100 & 100 & 98 & 98 & 89 & 92 \\
\hline 7 & 98 & 100 & 94 & 98 & 86 & 92 \\
\hline 14 & 95 & 96 & 91 & 97 & 82 & 89 \\
\hline 21 & 92 & 95 & 85 & 96 & 76 & 87 \\
\hline
\end{tabular}

*See Table: 3. 


\section{REFRENCES}

Anand, S.K.; R.A. Srinivasan and L.K. Rao (1984). Antibacterial activity associated with Bifidobacterium bifidum. Cult. Dairy Prod. J. 19(4): 6-8. AOAC, (2000). Official Methods of Analysis $\left(25^{\text {th }}\right.$ Ed.), pp. 20-49. Association of Official Analytical Chemists. Washington D.C., USA.

Bodyfelt, F.W.; J. Tobias and G.M. Trout (eds.) (1988). Sensory evaluation of cultured milk products. In: The Sensory Evaluation of Dairy Products. pp. 227-299. AVI Book pub. by Van Nostrand Reinhold, New York, USA.

Bourne, M.C. (ed.) (1982). In: Food Texture and Viscosity Concept and Measurement. pp. 82-159 \& 199-245. Academic Press Inc., New York, USA.

Coninck, V. De (1996). C* Delight MDO, an All Natural Easy Processing Fat Mimetic, Application Centre Food, Vilvoorde, Belgium.

Dave, R.I. and N.P. Shah (1996). Evaluation of media for selective enumeration of Streptococcus thermophilus, Lactobacillus delbrueckii ssp. bulgaricus, Lactobacillus acidophilus, and bifidobacteria. J. Dairy Sci. 79: 1529-1536.

El-Kenany, Y.M. (1996). Properties of cultured buffalo's cream manufactured with different starter cultures. Annals Agric. Sci. Moshtohor, 34(1): 285-299.

Fayed, A.E.; Azza M. Farahat and Gehan A.M. Hussein (2006). Production of light calorie whipped cream using fat mimetics and stevioside. Proc. $10^{\text {th }}$ Conf. Agric. Dev. Res., Fac. Agric., Ain Shams Univ., Cairo, Annals Agric. Sci., Sp. Issue, In press.

Hansen, R. (1985). Bifidobacteria have come to stay. North. Euro. Dairy J. 51(3): 79-83.
Harrison, V.C. and G. Peat (1975). Serum cholesterol and bowel flora in the newborn. J. Clin. Nutr., 28(12): 13511355.

Hekmat, S. and D.J. McMahon (1992). Survival of Lactobacillus acidophilus and Bifidobacterium bifidum in ice cream for use as a probiotic food. J. Dairy Sci. 75: 1415-1422.

Hoover, D.G. (1993). Bifidobacteria: Activity and potential benefits. Food Technol. 67(6): 120-124.

Kebary, K.M.K.; S.A. Hussein and R.M. Badawi (1998). Improving viability of bifidobacteria and their effect on frozen ice cream. Egyptian J. Dairy Sci. 26: 319-337.

Kim, H.S. and S.E. Gilliland (1984). Effect of viable starter culture bacteria in yogurt on lactose utilization in humans. $\boldsymbol{J}$. Dairy Sci. 67: 1-6.

Kurmann, J.A. and J.L. Rasic (1991). The health potential of products containing bifidobacteria. In: Therapeutic Properties of Fermented Milks. pp. 117-158. Robinson, R.K. (ed.). Elsevier Appl. Sci., London, UK.

Lees, G.J. and G.B. Jago (1969). Methods for the estimation of acetaldehyde in cultured dairy products. Aust. J. Dairy Technol. 24: 181-185.

Lees, G.J. and G.B. Jago (1970). The estimation of diacetyl in the presence of the carbonyl compounds. J. Dairy Res. 37:129- 132.

Marshall, R. T. (ed.) (1992). In: Standard Methods for the Examination of Dairy Products. $\left(1^{\text {th }}{ }^{\text {Ed. }}\right.$ E), pp. 433-531. Amer. Public Health Assoc., Washington, DC.

Oda, M.; H. Hasegawa; S. Komatsu; M. Kambe and F. Tsuchiya (1983). Anti-tumor polysaccharide from Lacto- 
bacillus species. Agric. \& Biol. Chem. 47(7): 1623-1625.

Poupard, J.A.; I. Husain and R.F. Norris (1973). Biology of the bifidobacteria. Bacteriol. Rev. 37: 136-165.

Rasic, J.L. (1983). The role of dairy foods containing bifidobacteria and acidophilus bacteria in nutrition and health. North. Euro. Dairy J. 4:1-5.

Rasic, J.L. and J.A. Kurmann (eds.) (1983). In: Bifidobacteria and Their Roles. pp. 12 \& 124-158. Birkhauser Verlag, Basel, Switzerland.

Renner, E. and A. Renz-Schauen (eds.) (1986). In: Nutritive Value Tables for Milk and Milk Products. pp. 6 \& 153177. Pub. B. Renner, 6300 Giessen, Germany.

Robinson, R.K. (ed.) (1991). Microorganisms of fermented milk. In: Therapeutic Properties of Fermented Milks pp. 23-44. Elsevier Appl. Sci., London, UK.

Schuler-Malyoth, R.; A. Ruppert and F. Muller (1968). The microorganisms of the bifidus group (Lactobacillus bifidus). I. Historical review, nutrition, physiological and therapeutic aspects, morphology, culture procedures and taxonomy. Milchwissenschaft 23(9): 356-360.

SPSS (1998). Statistical Package for Social Science. SPSS for Windows
Computer Program. Ver. 6.1. SPSS Inc., Chicago, Illinois, USA.

Start, P.L. and A. Lee (1982). The microbial ecology of large bowel of breastfed and formula-fed infants during the first year. J. Med. Microbiol. 15(2): 189203.

Terzaghi, B.E. and W.E. Sandine (1975). Improved medium for the lactic streptococci and bacteriophages. Appl. Microbiol. 29: 807-813.

Tharp, B.W. and T.V. Gottemoller (1990). Light frozen desserts: effects of compositional changes on processing and sensory characteristics. Food Technol. 44: 86-87.

Toledo, T.T. (ed.) (1980). In: Fundamentals of Food Process Engineering pp. 1-29. AVI Pub. Co. West Port, Connecticut, USA.

Walstra, P. and R. Jenness (eds.) (1984). Nutritive value. In: Dairy Chemistry and Physics. pp. 358-375. A WileyInterscience Pub., John Wiley \& Sons, New York, USA.

Wilson, E.D.; C.W. Seo; A. Shahbazi and S.A. Ibrahim (2004). Dairy Foods: Cheese and Microbiology. Institute of Food Technologists (IFT) Ann. Meeting and Food Expo ${ }^{\circledR}$., p. I., July 12-16, Las Vegas, Nevada, USA. 
بحلة اتحاد الجحامعات العربية للدراسات والبحوث الزراعية ، جامعة عين شمس ، القاهرة ،14(2) ، 697- 2006 ، 2006 إنتاج قشدة متخمرة حيوية منخفضة السعرات الحرارية

[44]

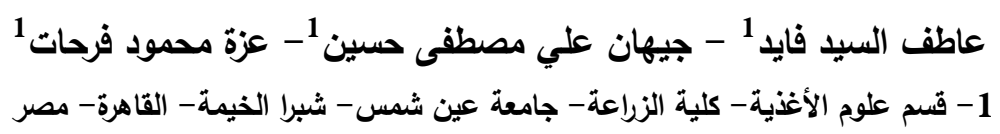

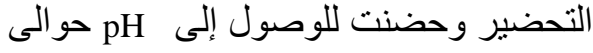

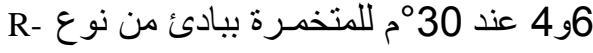

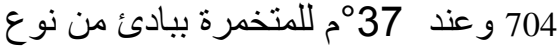

ABT-2

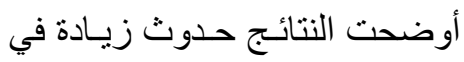

محتـوى القشـدة المتخمـرة من البروتين

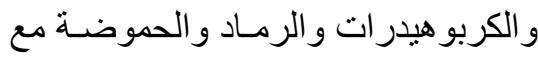

استبدال الدهن بينما حدث انخفاض في كل

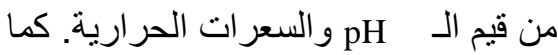

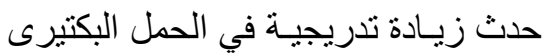

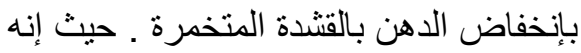
فى المنتج المتخمر ببادئ المزر عة الثانية نمى Lb. acidophilus وساد سائر السلالات المصاحبـة له بغض النظر عن نسبة الدهن أو والو

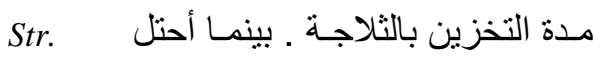
thermophilus وتحلاه و Bifidobacterium sp. Str. بعد ذلك بل فـاق عدد بكتيريا

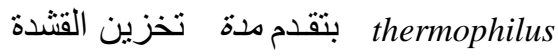

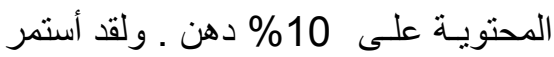

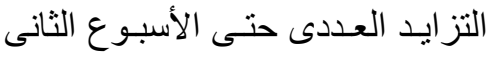
لميكروب Lb. acidophilus وحتى الأسبوع الأول لميكروب Bifidobacterium sp. بينما بدأ ميكروب Str. thermophilus فئى
استهـدف البحث إنتاج قتـدة متخمرة

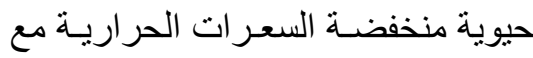
در اسـة علاقـة ذلك بالخـواص التركيبية

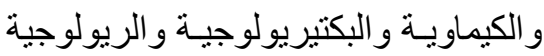
و الحسية مـع التركيز على الحمل البكتيرى ولئي

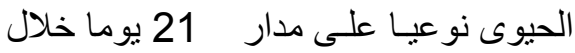
التخزين بالثناجـة. ولتحقيـق ذلك تم إنتاج

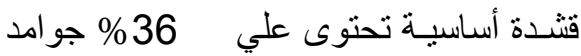

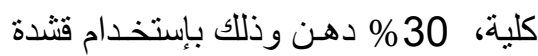

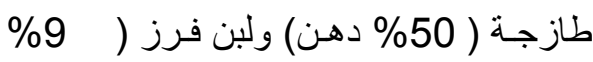

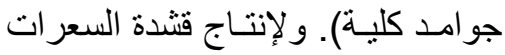
الحرارية تم خفض الدهن إلى 20\% و10\% إعتمادا علي إستخدام الدهن المقلد سمبلس إلس إس \% عimplesse $100^{\circledR}$ بديل دهنى يحل محل 100\% دهـن ، كما تم

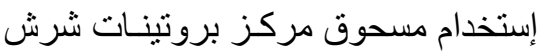

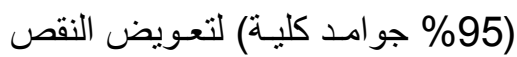
الحادث في محتوى القشدة من الجو امد الكلية

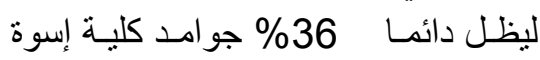
بالكنترول . وقد تم تجنيس جميع المعاملات وذللك عند 55 - 60م ثم تم إجر اء معاملة

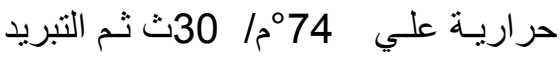
السريع إلى درجة الحـر ارة المناسبـة حيث لقحت بنسبة 2\% بإستخدام بادئات حديثة 
الإنخفاض منذ اليوم الأول للتخزين بالثناجة. الأبتدائى للقتدة المتخمرة وخاصة ببادئ

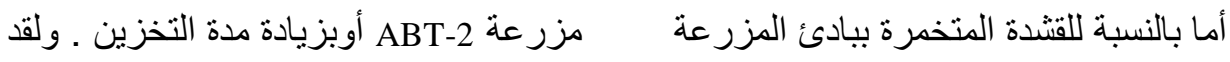

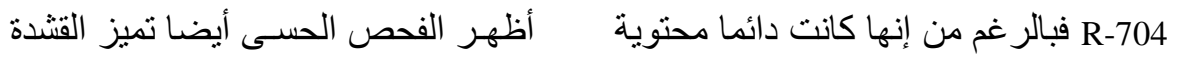
على أعداد كبيرة إلا إنها سلكت إتجاها

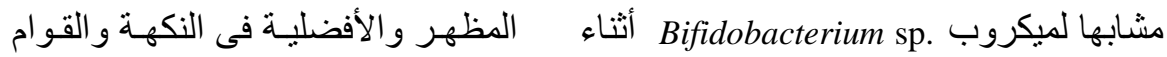

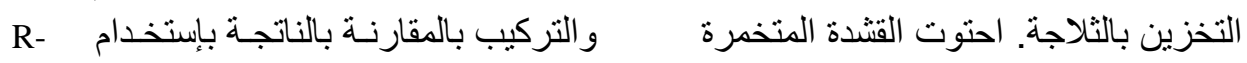

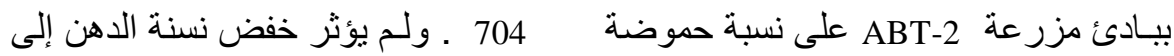

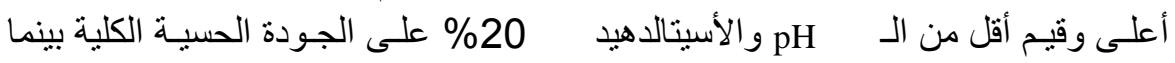

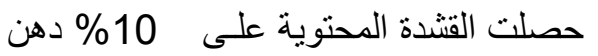
و المخمرة بإستخدام

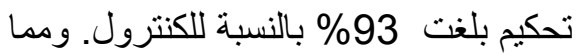
سبق يمكن الأستتناج أنه بمكن بنجاح بإنتاج

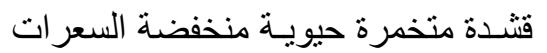

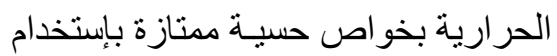

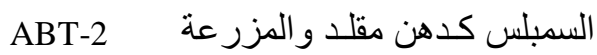
كبادئ بكتيري.

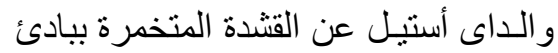

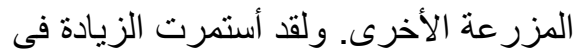

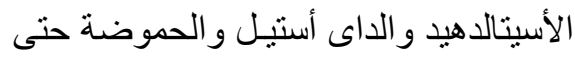

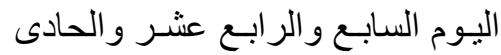

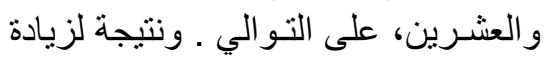
المحتوى البروتينى على حساب الدهن

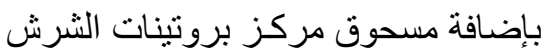

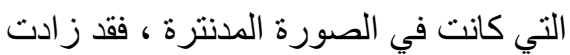

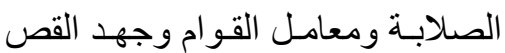

تحكيم: أ.د عبده السيد شحاتة أ.د سنيه محمود عبده أد مبده 